\title{
Scope and applicability of information stored in natural history collections - a case study based on the largest museum collections of Tenebrionidae (Coleoptera) in Poland
}

\author{
Piotr TYKARSKI
}

Dept. of Ecology, Faculty of Biology, University of Warsaw, Banacha 2, 02-097 Warszawa, Poland, e-mail: ptyk@apoczta.onet.pl

\begin{abstract}
Collections of specimens in museums of natural history constitute very rich sources of information, containing data that can be analyzed in many ways and answer various types of questions. The aim of this article was to analyze the data content of three big collections of specimens of darkling beetles (Coleoptera, Tenebrionidae) and to show possible uses of different types of analysis with a specific focus to GIS-based methods. The source material was analyzed with regard to collections, species and collecting persons, using a number of aspects, both as summaries and spatial distribution analyses, such as counts of records, species, specimen localities, UTM squares, collection dates.
\end{abstract}

Key words: Coleoptera, Tenebrionidae, specimen labels, natural history collections, faunistics, spatial analysis, UTM squares, Poland

\section{INTRODUCTION}

Museums of natural history contain rich sources of biological data, providing material for several fields of scientific research, mostly connected with taxonomy, biogeography, and phylogeny. This is due to the very character of objects that they hold. Specimens of organisms, collected, preserved and deposited in a museum, are physical evidence of the reality of times when they were collected. If a collection is big enough, one can analyze various aspects of information it contains. It is possible under one condition: specimens themselves have to be well documented. The quality and detail level of data given on labels, concerning collecting events, determine feasibility of most of the possible future analyses connected with particular specimens.

Recently, during the last 10 years, the information content stored in museum collections has been given much more attention from science than ever before. We can observe a kind of renaissance of natural history collections, linked with and actually catalyzed by current progress in information technologies. It is so called biodiversity informatics that has increased interest of many scientists in museum collections and caused a change of their perception (SOBERón \& PETERSon 2004, Johnson 2007). This is less and less the old-fashioned, traditional, almost non-scientific field of biological sciences; the modern approach has made it possible to understand multifaceted and 
complex picture of collections and scientific potential that they have (Krishtalka \& HUMPHREY 2000).

Thanks to computer networks and distributed information systems, it is now possible to aggregate data from a vast number of datasets presenting primary information held in collections all over the world. If data available this way are of sufficient quality, it is possible e.g. to map species distributions or to create regional checklists. Every single specimen represented in a digital form can become a source of valuable information for certain types of analyses, provided that the quality requirements of its description are met (ChAPMAN 2005).

The biggest network of biodiversity information - the Global Biodiversity Information Facility (GBIF) - is in fact, from technical point of view, an extension of several museum networks, sharing data about their specimens, using a common data format (WhEELER 2004). After some improvements, the original concepts and ideas turned out to be suitable for exchanging information about any primary biological records (e.g. observations, molecular data). At the moment, the total count of GBIF records based on museum specimens is ca. 80 million and can be used together with corresponding observation data.

In Poland, this kind of modern approach to resources of national museum institutions started in 2004, when the Polish Biodiversity Information Network (PolBIN, a Polish acronym $K S I B$ ) was created. The application of technologies developed by GBIF and sharing data with the global network enabled a number of Polish collections to be digitized and properly adjusted to present-day standards and requirements (KozAKIEWICZ \& TYKarski 2007). However, despite PolBIN's achievements (ca. 1,5 million records available on-line, ca. $25 \%$ based on collections) this is the beginning of works that are necessary to develop an effective information system that would be useful for a wide range of scientific applications. Only a small percent of collections has been digitized so far. Beside the organizational challenges and necessary understanding of digitization advantages and sharing data by collection owners, the process itself is work and timeconsuming.

The properly structured information unit should contain both data (species name, locality and date of the collection event) and metadata (gathering person, identifier, optionally verifier, collection method, etc.). Digitization of the verbatim information is usually only a starting point for a qualified electronic record especially in its geographic part. To be fully functional, it should be georeferenced, enabling a user to include it into geographic analyses (CHAPMAN \& WIECZOREK 2006). These requirements are still rarely met in databases describing museum collections. Even when the material of a particular collection has all information elements in place, it happens that it is only partially digitized. Post-processing of records, especially adding georeferences, is also not a common practice.

The aim of this article is to show the scope of information contained in data derived from typical entomological collections, as a case study based on tenebrionid collections from three largest sources for this family in Poland. This includes different perspectives and examples of a number of uses of properly structured data. 
Table 1. A schema of the data table and example original data entries from the source data to this article. When an entry contained two dates, it was transformed into two records; for single dates only one record was created.

\begin{tabular}{llllllll}
\hline Species & KFP region & Locality & UTM & Date I & Date II & Collector & Museum \\
\hline Lagria hirta & Baltic Coast & $\begin{array}{l}\text { Między- } \\
\text { zdroje }\end{array}$ & VV67 & 12 VII 1966 & 23 VII 1966 & AO & MIZ \\
Lagria hirta & $\begin{array}{l}\text { Pomeranian } \\
\text { Lake District }\end{array}$ & $\begin{array}{l}\text { Bielinek } \\
\text { nad Odrą }\end{array}$ & VU46 & 2 VIII 1985 & PS & ISEA \\
$\begin{array}{l}\text { Tenebrio } \\
\text { molitor }\end{array}$ & $\begin{array}{l}\text { Kraków-Wieluń Kraków- } \\
\text { Upland }\end{array}$ & $\begin{array}{l}\text { Zwierzyniec } \\
\text { ZA14 }\end{array}$ & 22 VIII 1968 & 21 VII 1976 & $\begin{array}{l}\text { MG } \\
\& \text { MB }\end{array}$ & ISEA \\
\hline
\end{tabular}

\section{Methods}

The data used in this analysis come from the article by IwAN et al. (2010), who described in detail methods used to create this dataset. It is based on the largest collections of Tenebrionidae from three institutions: Institute of Systematics and Evolution of Animals PAS, Cracow (ISEZ), Museum and Institute of Zoology PAS, Warsaw (MIZ) and Upper Silesian Museum, Bytom (USMB), where voucher specimens are deposited. Although the material is rich and carefully prepared, it does not contain full information about all analyzed specimens. In case of series of specimens from the same locality and different dates of collection, only edge dates of the series were noted (Table 1). Yet, lower time resolution caused by this simplification is not an obstacle and has little influence on the requirements of the analyses presented here. Where an original data entry was had two dates, it was transformed into two records, which had different dates and the rest of fields identical. In some cases, dates were absent as they were missing from the original specimen labels. Apart from the text description of a locality, every record in the analyzed material had UTM coordinates (grid $10 \times 10 \mathrm{~km}$ ) assigned. Additionally, each locality was assigned to a faunistic region, according to the system introduced in Catalogus Faunae Poloniae (KFP), further in the text referred to as a "KFP region". Although the system itself has many disadvantages and should be replaced with more adequate solutions, it is still in use in Polish entomological literature and, therefore, it should be possible to refer to it as a legacy system in future.

Maps were prepared using ESRI ArcGIS 9.3 in the PUWG 1992 coordinate system. All the maps use the same template, presenting boundaries of Poland, bigger towns (in darker gray), borders of KFP regions and the UTM grid: squares $10 \times 10 \mathrm{~km}$ with dotted lines and squares $100 \times 100 \mathrm{~km}$ with solid lines. 


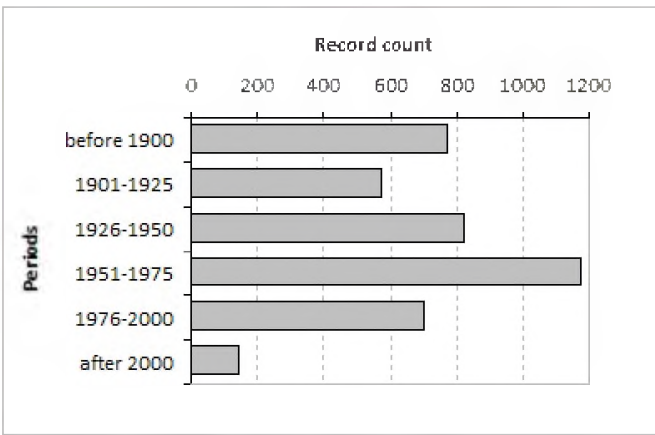

Fig. 1. Distribution of records in the time range of the analyzed material. The data from the XIX century are pooled; newer data divided into 25 -year intervals.

\section{RESULTS}

\section{General information about the data content}

The source data comprise specimens of 78 species, collected from 1124 localities at 598 UTM squares by 177 collecting persons (Table 2). The oldest record dates back to

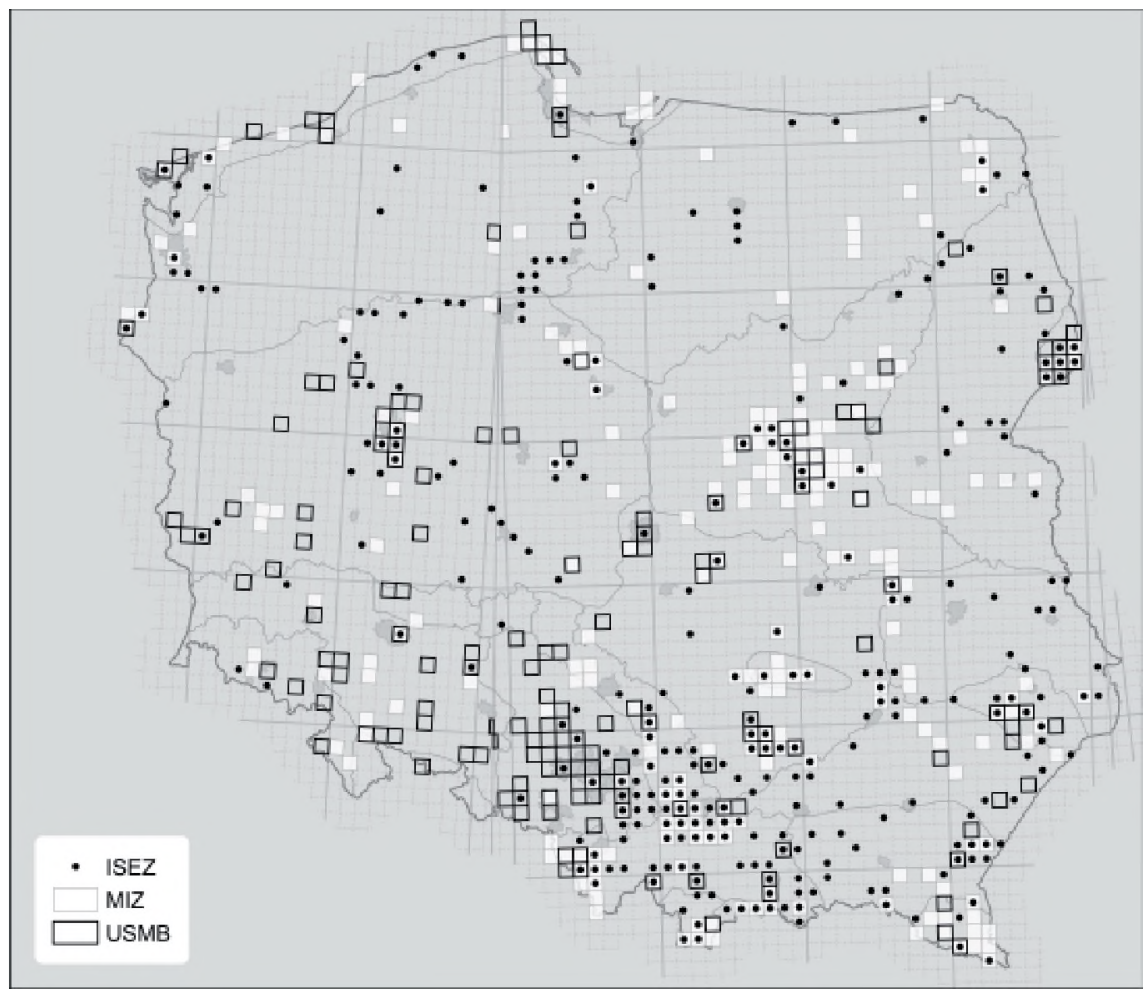

Fig. 2. Distribution of source localities for the three examined collections. Each collection is coded with a different colour. 
1859 and the newest data were collected in 2010. A closer look at numbers of records in consecutive periods reveals the highest values in 1951-1975, and subsequent decrease (Fig. 1). If the number of records is proportional to the actual number of specimens, these values might be related to the rate of inflow of new specimens to the collections. The three maximal record numbers were noted in Opatrum sabulosum, Lagria hirta, and Tenebrio molitor. The oldest record is connected with Isomira murina, caught in 1859 (leg. A. WAGA, ISEZ collection). Isomira murina, Bolitophagus reticulatus, Corticeus unicolor, and Platydema violaceum are species with longest ranges of record dates (the first one 151, others 135 years). The next part contains example analyses and summaries connected with GIS analyses of the data, divided for clarity into separate topics.

\section{Comparison of the collections}

Total numbers of species were comparable in each of the three examined collections (Table 2) - more than 60 in each case. There are remarkable differences in record counts, what is most probably connected with size of the collections. In comparison with MIZ and ISEA, the USMB tenebrionid collection is visibly more diverse, including similar species count from a much lower number of records and lower group of collectors. The geographical coverage of the collections is comparable and country-wide, although there is a noticeable bias in each one (Fig. 2). The USMB collection is more south-west oriented, ISEA - more south-east and the MIZ collection has more even distribution than the other two, being more dense around Warsaw. In many regions the collections overlap, in some of them suggesting a common history of collecting events or more attractive entomological collection places.

Table 2. Summary of data content in the analyzed material in respect to the three sources of information: ISEA, MIZ and USMB collections.

\begin{tabular}{lcccc}
\hline \multirow{2}{*}{ Museum } & \multicolumn{4}{c}{ Total counts } \\
\cline { 2 - 5 } & Taxa & Collectors & Records & UTM squares \\
\hline ISEA & 64 & 83 & 1661 & 332 \\
MIZ & 66 & 84 & 1573 & 273 \\
USMB & 63 & 51 & 681 & 179 \\
\hline
\end{tabular}

\section{Spatial distribution of the data - general summaries}

The analysis of record number per UTM square can be a kind of estimation of the research effort that had taken place in an area (Fig. 3). It is clear then which parts of the country receive more attention from coleopterists. According to this material this is Warsaw and its surroundings, Białowieża Forest, vicinities of Cracow, Pieniny Mts, Upper Silesia and Pogórze Przemyskie. There are also single smaller areas that were 
Species name

Allecula morio (Fabricius, 1787)

Allecula rhenana Bach, 1859

Alphitobius diaperinus (Panzer, 1797)

Alphitobius laevigatus (Fabricius, 1781)

Alphitophagus bifasciatus (Say, 1824)

Blaps halophila Fischer von Waldheim, 1822

Blaps lethifera lethifera Marsham, 1802

Blaps mortisaga (Linnaeus, 1758)

Blaps mucronata Latreille, 1804

Bolitophagus internuptus Illiger, 1800

Bolitophagus reticulatus (Linnaeus, 1767)

Centorus elongatus elongatus (Herbst, 1797)

Corticeus bicolor (Olivier, 1790)

Corticeus bicoloroides (Roubal, 1933)

Corticeus fasciatus (Fabricius, 1790)

Corticeus fraxini (Kugelann, 1794)

Corticeus linearis (Fabricius, 1790)

Corticeus longulus (Gyllenhal, 1827)

Corticeus pini (Panzer, 1799)

Corticeus suberis (Lucas, 1846)

Corticeus suturalis (Paykull, 1800)

Corticeus unicolor Piller \& Mitterpacher, 1783

Cryphaeus cornutus

(Fischer von Waldheim, 1823)

Crypticus quisquilius (Linnaeus, 1761)

\begin{tabular}{|ccr|}
\hline \multicolumn{2}{|c|}{ Data time range } \\
\hline $\begin{array}{c}\text { First } \\
\text { record }\end{array}$ & $\begin{array}{c}\text { Last } \\
\text { record }\end{array}$ & $\begin{array}{c}\text { Time } \\
\text { range }\end{array}$ \\
\hline 1873 & 2005 & 133 \\
\hdashline 1903 & 1975 & 73 \\
\hdashline 1938 & 2003 & 66 \\
\hdashline 1880 & 1938 & 59 \\
\hdashline 1972 & 1999 & 28 \\
\hdashline 1965 & 1971 & 7 \\
\hdashline 1903 & 1931 & 29 \\
\hdashline 1876 & 1994 & 119 \\
\hdashline 1935 & 1955 & 21 \\
\hdashline 1911 & 1912 & 2 \\
\hdashline 1873 & 2007 & 135 \\
\hdashline 1900 & 1900 & 1 \\
\hdashline 1889 & 1997 & 109 \\
\hdashline 1930 & 1932 & 3 \\
\hdashline 1889 & 1993 & 105 \\
\hdashline 1886 & 2004 & 119 \\
\hdashline 1907 & 1989 & 83 \\
\hdashline 1894 & 1994 & 101 \\
\hdashline 1876 & 1971 & 96 \\
\hdashline 1938 & 1938 & 1 \\
\hdashline 1921 & 2003 & 83 \\
\hdashline 1873 & 2007 & 135 \\
\hdashline 1937 & 1937 & 1 \\
\hdashline 1874 & 2004 & 131 \\
\hdashline
\end{tabular}

\begin{tabular}{|c|c|c|c|}
\hline \multicolumn{4}{|c|}{ Total counts } \\
\hline Areas & $\begin{array}{c}\text { UTM } \\
\text { squares }\end{array}$ & $\begin{array}{l}\text { Re- } \\
\text { cords }\end{array}$ & $\begin{array}{l}\text { Colle- } \\
\text { ctors }\end{array}$ \\
\hline 58 & 48 & 92 & 23 \\
\hline 11 & 10 & 18 & 2 \\
\hline 8 & 7 & 7 & 7 \\
\hline 5 & 3 & 11 & 4 \\
\hline 3 & 3 & 3 & 3 \\
\hline 1 & 1 & 4 & 2 \\
\hline 3 & 3 & 3 & 2 \\
\hline 63 & 60 & 92 & 29 \\
\hline 4 & 4 & 4 & 2 \\
\hline 3 & 3 & 3 & 3 \\
\hline 86 & 62 & 150 & 34 \\
\hline 1 & 1 & 1 & 1 \\
\hline 62 & 39 & 114 & 28 \\
\hline 1 & 1 & 2 & 2 \\
\hline 16 & 15 & 36 & 10 \\
\hline 15 & 11 & 18 & 11 \\
\hline 11 & 11 & 18 & 8 \\
\hline 14 & 13 & 18 & 10 \\
\hline 11 & 10 & 11 & 6 \\
\hline 1 & 1 & 1 & 1 \\
\hline 5 & 1 & 5 & 3 \\
\hline 72 & 51 & 131 & 26 \\
\hline 1 & 1 & 1 & 1 \\
\hline 147 & 120 & 207 & 52 \\
\hline
\end{tabular}

Count of KFP regions

Mate- KFP Com- Poo- Unique Unique mon led for $\mathrm{M}$. for KFP

$\begin{array}{cccccc}15 & 16 & 14 & 17 & 1 & 2 \\ 6 & 7 & 6 & 7 & & 1\end{array}$

$\begin{array}{llllll}7 & 6 & & 6 & 7 & 1\end{array}$

$\begin{array}{ccccccc}4 & 4 & 1 & 7 & 3 & 3 \\ 3 & 7 & 2 & 8 & 1 & 5\end{array}$

\begin{tabular}{lllllll}
3 & 7 & 2 & 8 & 1 & 5 \\
1 & 2 & 1 & 2 & & 1 \\
\hline & & & 3 & 9 & & 6
\end{tabular}

\begin{tabular}{cccccc}
1 & 2 & 1 & 2 & 1 \\
3 & 9 & 3 & 9 & 6 \\
15 & 13 & 9 & 19 & 6 & 4 \\
\hline 3 & 5 & 2 & 6 & 1 & 3
\end{tabular}




\begin{tabular}{|c|c|c|c|c|c|c|c|c|c|c|c|c|c|}
\hline Cteniopus sulphureus (Linnaeus, 1758) & 1882 & 2009 & 128 & 56 & 43 & 80 & 34 & 14 & 12 & 10 & 16 & 4 & 2 \\
\hline Cteniopus sulphuripes (Germar, 1824) & 1920 & 1920 & 1 & 1 & 1 & 1 & 1 & 1 & 5 & 1 & 5 & & 4 \\
\hline Diaperis boleti (Linnaeus, 1758 ) & 1876 & 2003 & 128 & 90 & 76 & 162 & 36 & 18 & 17 & 12 & 23 & 6 & 5 \\
\hline Eledona agricola (Herbst, 1783) & 1873 & 2003 & 131 & 55 & 49 & 95 & 27 & 15 & 15 & 11 & 19 & 4 & 4 \\
\hline Eledonoprius armatus (Panzer, 1799) & 1884 & 1884 & 1 & 1 & 1 & 1 & 1 & 1 & 3 & & 4 & 1 & 3 \\
\hline Gnatocerus cornutus (Fabricius, 1798) & 1900 & 2000 & 101 & 8 & 8 & 15 & 8 & 7 & 6 & 4 & 9 & 3 & 2 \\
\hline $\begin{array}{l}\text { Gonocephalum granulatum pusillum } \\
\text { (Fabricius, } 1792 \text { ) }\end{array}$ & 1896 & 1896 & 1 & 1 & 1 & 1 & 1 & 1 & & & 1 & 1 & \\
\hline Gonodera luperus luperus (Herbst, 1783) & 1879 & 1999 & 121 & 22 & 21 & 32 & 15 & 13 & 14 & 11 & 16 & 2 & 3 \\
\hline Hymenalia rufipes (Fabricius, 1792) & 1893 & 2003 & 111 & 26 & 22 & 33 & 17 & 10 & 15 & 8 & 17 & 2 & 7 \\
\hline Hymenophorus doublieri Mulsant, 1851 & 1959 & 1959 & 1 & 1 & 1 & 1 & 1 & 1 & 1 & & 2 & 1 & 1 \\
\hline Isomira murina murina (Linnaeus, 1758) & 1859 & 2009 & 151 & 157 & 105 & 223 & 36 & 18 & 17 & 14 & 21 & 4 & 3 \\
\hline Laena reitteri Weise, 1877 & 1876 & 1992 & 117 & 10 & 8 & 15 & 10 & 2 & 2 & 2 & 2 & & \\
\hline Lagria atripes Mulsant \& Guillebeau, 1855 & 1961 & 2003 & 43 & 9 & 9 & 12 & 10 & 7 & 3 & 2 & 8 & 5 & 1 \\
\hline Lagria hirta (Linnaeus, 1758) & 1878 & 2009 & 132 & 201 & 153 & 280 & 65 & 23 & 22 & 22 & 23 & 1 & \\
\hline Latheticus oryzae Waterhouse, 1880 & 1938 & 1956 & 19 & 3 & 3 & 3 & 2 & 3 & & & 3 & 3 & \\
\hline Melanimon tibialis tibialis (Fabricius, 1781) & 1874 & 2007 & 134 & 125 & 98 & 189 & 48 & 16 & 12 & 12 & 16 & 4 & \\
\hline Mycetocharis axillaris (Paykull, 1799) & 1884 & 2004 & 121 & 51 & 39 & 80 & 12 & 14 & 14 & 12 & 16 & 2 & 2 \\
\hline Mycetocharis flavipes (Fabricius, 1792) & 1879 & 1999 & 121 & 62 & 46 & 104 & 16 & 12 & 16 & 11 & 17 & 1 & 5 \\
\hline Mycetocharis humeralis (Fabricius, 1787) & 1888 & 1991 & 104 & 22 & 19 & 35 & 11 & 9 & 9 & 6 & 12 & 3 & 3 \\
\hline Mycetocharis maura (Fabricius, 1792) & 1879 & 1999 & 121 & 30 & 29 & 48 & 13 & 10 & 14 & 10 & 14 & & 4 \\
\hline Mycetocharis pygmaea (Redtenbacher, 1874) & 1904 & 1904 & 1 & 1 & 1 & 1 & 1 & 1 & 4 & 1 & 4 & & 3 \\
\hline Myrmechixenus subterraneus Chevrolat, 1835 & 1878 & 1981 & 104 & 13 & 12 & 18 & 6 & 8 & 12 & 5 & 15 & 3 & 7 \\
\hline Nalassus convexus (Comolli, 1837) & 1884 & 1896 & 13 & 2 & 2 & 2 & 1 & 1 & & & 1 & 1 & \\
\hline Nalassus dermestoides (Illiger, 1798) & 1874 & 2006 & 133 & 86 & 69 & 148 & 38 & 17 & 13 & 12 & 18 & 5 & 1 \\
\hline Nalassus laevioctostriatus (Goeze, 1777) & 1937 & 1982 & 46 & 2 & 2 & 2 & 2 & 1 & 6 & & 7 & 1 & 6 \\
\hline Neatus picipes (Herbst, 1797) & 1888 & 1995 & 108 & 19 & 13 & 52 & 15 & 5 & 9 & 5 & 9 & & 4 \\
\hline Neomida haemorrhoidalis (Fabricius, 1787) & 1878 & 2003 & 126 & 23 & 21 & 44 & 15 & 11 & 8 & 7 & 12 & 4 & 1 \\
\hline Omophlus pubescens (Linnaeus, 1758) & 1874 & 2003 & 130 & 45 & 42 & 67 & 26 & 13 & 17 & 12 & 18 & 1 & 5 \\
\hline $\begin{array}{l}\text { Oodescelis melas } \\
\text { (Fischer.von Waldheim .1823) }\end{array}$ & 1916 & 1918 & 3 & 2 & 2 & 2 & 2 & 2 & 3 & & 5 & 2 & 3 \\
\hline
\end{tabular}


Data time range

Opatrum riparium Scriba, 1865

Opatrum sabulosum sabulosum

(Linnaeus, 17.61).

Palorus depressus (Fabricius, 1790)

Palorus ratzeburgii (Wissmann, 1848)

Palorus subdepressus Wollaston, 1864

Pedinus femoralis (Linnaeus, 1767)

Pentaphyllus testaceus (Hellwig, 1792)

Phylan gibbus (Fabricius, 1775)

Platydema dejeanii Laporte \& Brullê, 1831

Platydema violaceum (Fabricius, 1790)

Podonta nigrita (Fabricius, 1794)

Prionychus ater (Fabricius, 1775 )

Prionychus melanarius (Germar, 1813

P seudocistela ceramboides ceramboides

Linnaejs 17.61

etallicum metallicum

(Fabricius, 1792)

Stenomax aeneus (Scopoli, 1763 )

Tenebrio molitor Linnaeus, 1758

Tenebrio obscurus Fabricius, 1792

Tenebrio opacus Duftschmid, 1812

Tribolium castaneum (Herbst, 1797)

Tribolium confusum Jacquelin du Val, 1862

Tribolium destructor Uyttenboogaart, 1933

Tribolium madens (Charpentier, 1825)

Uloma culinaris (Linnaeus, 1758)

Uloma rufa (Piller \& Mitterpacher, 1783)
Total counts

Count of KFP regions

$\overline{0}$

First Last Time UTM Re- Colle- Mate- KFP Com- Poo- Unique Unique record record range Areas squares cords ctors rial KFP mon led for M. for KFP

\begin{tabular}{|c|c|c|c|c|c|c|c|c|c|c|c|c|}
\hline 1878 & 1994 & 117 & 23 & 18 & 34 & 13 & 9 & 11 & 6 & 14 & 3 & 5 \\
\hline 1878 & 2003 & 126 & 176 & 131 & 327 & 45 & 19 & 18 & 17 & 20 & 2 & 1 \\
\hline 1885 & 2007 & 123 & 7 & 6 & 24 & 5 & 3 & 8 & 2 & 9 & 1 & 6 \\
\hline 1936 & 1938 & 3 & 2 & 2 & 2 & 1 & 2 & 6 & 2 & 6 & & 4 \\
\hline 1953 & 1981 & 29 & 2 & 2 & 2 & 2 & 2 & 1 & 1 & 2 & 1 & \\
\hline 1880 & 1996 & 117 & 24 & 18 & 64 & 22 & 6 & 4 & 3 & 7 & 3 & 1 \\
\hline 1879 & 1999 & 121 & 22 & 20 & 47 & 12 & 8 & 11 & 8 & 11 & & 3 \\
\hline 1912 & 1997 & 86 & 21 & 20 & 44 & 16 & 2 & 3 & 1 & 4 & 1 & 2 \\
\hline 1879 & 1999 & 121 & 26 & 13 & 34 & 12 & 6 & 5 & 5 & 6 & 1 & \\
\hline 1872 & 2006 & 135 & 21 & 19 & 25 & 16 & 10 & 12 & 7 & 15 & 3 & 5 \\
\hline 1896 & 1900 & 5 & 3 & 2 & 3 & 1 & 1 & 2 & & 3 & 1 & 2 \\
\hline 1878 & 2006 & 129 & 63 & 52 & 101 & 29 & 13 & 17 & 13 & 17 & & 4 \\
\hline 1890 & 1971 & 82 & 21 & 17 & 29 & 9 & 9 & 9 & 8 & 10 & 1 & 1 \\
\hline 1879 & 2004 & 126 & 73 & 64 & 97 & 23 & 18 & 21 & 16 & 23 & 2 & 5 \\
\hline 1876 & 2004 & 129 & 91 & 61 & 133 & 37 & 16 & 14 & 11 & 19 & 5 & 3 \\
\hline 1879 & 2003 & 125 & 76 & 60 & 121 & 31 & 16 & 10 & 9 & 17 & 7 & 1 \\
\hline 1878 & 2010 & 125 & 139 & 111 & 254 & 63 & 22 & 23 & 22 & 23 & & 1 \\
\hline 1879 & 1965 & 87 & 16 & 15 & 32 & 9 & 10 & 13 & 8 & 15 & 2 & 5 \\
\hline 1937 & 1999 & 63 & 7 & 7 & 14 & 6 & 3 & 3 & 1 & 5 & 2 & 2 \\
\hline 1878 & 1995 & 118 & 16 & 15 & 21 & 14 & 9 & 11 & 5 & 15 & 4 & 6 \\
\hline 1899 & 1972 & 74 & 8 & 7 & 11 & 5 & 7 & 12 & 5 & 14 & 2 & 7 \\
\hline 1956 & 2000 & 45 & 9 & 9 & 17 & 12 & 8 & 6 & 3 & 11 & 5 & 3 \\
\hline 1903 & 1989 & 87 & 7 & 7 & 13 & 6 & 5 & 9 & 3 & 11 & 2 & 6 \\
\hline 1879 & 2007 & 129 & 45 & 32 & 81 & 25 & 11 & 13 & 9 & 15 & 2 & 4 \\
\hline 1878 & 2008 & 131 & 72 & 60 & 99 & 35 & 17 & 12 & 11 & 18 & 6 & 1 \\
\hline
\end{tabular}


evidently better investigated than others (e.g. Bielinek Reserve at the western border, or Zamość area in the south-east).

Similar conclusions may be drawn from the analysis of species numbers recorded from UTM squares (Fig. 4). In this case one can see distinct "hot-spots", showing much higher species richness than in other places. Without doubts, this is connected with higher sampling effort, mentioned earlier. There are a few areas in the analyzed material, showing more than 20 tenebrionid species: Warsaw (DC99, EC19) and Cracow (DA14, DA24) surroundings, Bialowieża (FD94), Bielinek reserve, Zamość vicinities (FB30 between Szczebrzeszyn, Bilogoraj and Krasnobród), Piekary Śląskie (CA58).

Both approaches suggest also that most of the country is poorly known - there are no records in none of the three biggest tenebrionid collections, and a high proportion of existing data come from a single collecting event ( $=$ a single record).

\section{Species statistics and examples of spatial analyses}

Basic statistics for all the species are summarized in Table 3. The three species recorded from the maximum number of localities/UTM squares are Lagria hirta, Opatrum sabulosum, and Isomira murina (Table 3). In the analyzed material Allecula morio, Bolitophagus reticulatus, Corticeus unicolor, Crypticus quisquilius, Eledona agricola, Isomira murina, Lagria hirta, Melanimon tibialis, Nalassus dermestoides, Platydema violaceum, Tenebrio molitor and Uloma rufa have the longest history of research - all of them have been recorded for more than 130 years. 5 species: Crypticus quisquilius, Lagria hirta, Melanimon tibialis, Opatrum sabulosum, and Tenebrio molitor were collected by more than 40 persons.

Mapping species distributions and spatial analyses may help to summarize current knowledge or even to plan areas and topics for the future research. Here, maps were used to assess representativeness of data about general distribution of species in the analyzed material by comparing them with the respective data from KFP. The analysis of overlapping of species distribution at the level of KFP regions showed four patterns in the compared data. They are presented below together with example species and criteria used to distinguish them:

- high similarity: the analyzed distribution of a species fits well or exactly to the compared distribution in KFP (Fig. 5). Criterion: high proportion of overlapping regions to the total number of regions.

- general low similarity: the analyzed distribution of a species is remarkably different from the compared distribution in KFP (Fig. 6). Criterion: low proportion of overlapping regions to the total number of regions.

- low similarity with high coverage: the distributions differ, but the analyzed coverage is wider than the compared coverage in KFP (Fig. 7). Criterion: high proportion of regions unique for the analyzed distribution to the total number of regions.

- low similarity with low coverage: the distributions differ, but the analyzed coverage is smaller than the compared coverage in KFP (Fig. 8). Criterion: high proportion of regions unique for the KFP distribution to the total number of regions. 


\section{Intensity of exploration and occurrence data validity}

Colour-coding of collection dates and plotting them on a UTM grid has several uses. A view on dates of the first records from an area (Fig. 10) shows the beginning of the history of research for sites studied over a longer period on one hand, and the areas that have been only recently explored and may need further research, on the other. The analyzed data clearly show areas of Warsaw, Cracow, Upper Silesia, Beskidy, Tatra Mts. and the south-eastern Poland, as well as Bialowieża and Szczecin as the first regions that have been explored with respect to the history of knowledge of tenebrionid fauna. An opposite type of observation may be made looking at the regions of Pomorskie and Mazurskie Lakelands - many areas there were investigated very recently.

Unlike in in the previous approach, maps showing dates of the last records (Figs 5-8) can be used to assess for which areas the current data exist, and where information on species occurrence is outdated. The same kind of coding in respect to the pooled data (Fig. 9) revealed areas of the country where the last research (in regard to the analyzed material, of course) took place in the XIX century and no further data exist. Amazingly, there are more than 20 such UTM squares, located also in regions with the longest history of entomological research - near Warsaw, Cracow, Zamość and in Silesia.

When the distribution of the first records may be compared to a bottom surface of the "cloud of information", the distribution of the last records corresponds to its upper surface. Mapping time ranges between the first and the last record from (Fig. 11) would then refer to thickness of the cloud. It may be an estimate of the research effort at sites of interest that can help to answer questions about completeness of knowledge about a particular area.

\section{Activity of the collectors}

The whole source material comprised specimens collected by 178 persons (Table 4 shows statistics for only top 30 persons contributing most of the records). The biggest number of records in the analyzed material comes from specimens collected by B. Burakowski (710), S. Stobiecki (363) and Sz. Tenenbaum (236). Burakowski and TenenBaum, as well as W. Mączý́śs contributed most in terms of number of species in the collections (respectively $51,41,45$ ). The maximum number of source localities included in materials of a single collector was found also for the first two persons and D. KuBIsz $(144,72,71$ UTM squares respectively). Most of the collectors had operated in certain regions of the country, or at least it is often easy to show the area of their most intense collection activities, as in cases of B. KotULA or F. KIRSCH (Fig. 12). There was also a group of collectors that acquired specimens from numerous localities, scattered all around Poland; the most distinct case represented by B. Burakowski (Fig. 13).

Generally, summarized plot of activities of collectors (Fig. 14) gives a similar view to the formerly presented maps that may be treated as a kind of estimates of research effort (Figs $3,4,11$ ). In this case there is maybe the most straightforward relation between attractiveness of an area (whatever was its reason) and the number of collecting visitors. 
Table 4. Basic statistics for collectors of specimens in the analyzed material. Only collectors with more than 20 records are shown.

\begin{tabular}{|c|c|c|c|c|c|c|}
\hline \multirow{2}{*}{ Collector } & \multirow{2}{*}{ First year } & \multirow{2}{*}{ Last year } & \multicolumn{4}{|c|}{ Total counts } \\
\hline & & & Species & Records & Areas & UTM squares \\
\hline Bartoszyński A. & 1927 & 1939 & 30 & 77 & 21 & 19 \\
\hline Bielawski R. & 1947 & 1973 & 21 & 74 & 54 & 45 \\
\hline Buchholz L. & 1974 & 1999 & 18 & 30 & 25 & 21 \\
\hline Bunalski M. & 1983 & 1994 & 19 & 33 & 22 & 20 \\
\hline Burakowski B. & 1930 & 1997 & 51 & 710 & 258 & 144 \\
\hline Ciszkiewicz H. & 1921 & 1939 & 20 & 55 & 24 & 19 \\
\hline Dobosz R. & 1989 & 2007 & 22 & 45 & 25 & 20 \\
\hline Eichler W. & 1911 & 1963 & 19 & 37 & 16 & 15 \\
\hline Fejfer $F$ & 1905 & 1941 & 22 & 38 & 10 & 7 \\
\hline Gutowski J.M. & 1975 & 2004 & 26 & 42 & 29 & 24 \\
\hline Iwan D. & 1981 & 1993 & 20 & 42 & 13 & 12 \\
\hline Jedryczkowski W. & 1984 & 2009 & 14 & 34 & 21 & 16 \\
\hline Kirsch F. & 1913 & 1942 & 30 & 88 & 26 & 23 \\
\hline Kotula B. & 1872 & 1898 & 31 & 157 & 46 & 21 \\
\hline Kubisz D. & 1983 & 2009 & 38 & 161 & 107 & 71 \\
\hline Maczyński W. & 1884 & 1982 & 45 & 185 & 29 & 25 \\
\hline Makólski J. & 1910 & 1953 & 15 & 39 & 19 & 17 \\
\hline Mazur E. & 1912 & 1941 & 21 & 72 & 49 & 27 \\
\hline Mazur M. & 1979 & 2003 & 13 & 61 & 57 & 42 \\
\hline Melke A. & 1981 & 1991 & 15 & 26 & 17 & 14 \\
\hline Mlynarski J.K. & 1982 & 1991 & 14 & 30 & 23 & 14 \\
\hline Mroczkowski M. & 1948 & 1962 & 17 & 31 & 22 & 20 \\
\hline Nowotny $\mathrm{H}$. & 1925 & 1938 & 21 & 41 & 21 & 18 \\
\hline Pawlowski J. & 1959 & 2004 & 21 & 58 & 42 & 34 \\
\hline Popek S. & 1907 & 1939 & 19 & 59 & 26 & 10 \\
\hline Rybiński M. & 1876 & 1904 & 24 & 30 & 21 & 6 \\
\hline Stachowiak P. & 1974 & 1987 & 14 & 24 & 13 & 10 \\
\hline Stobiecki S. & 1876 & 1942 & 39 & 363 & 132 & 72 \\
\hline Szymczakowski W. & 1947 & 1972 & 15 & 127 & 54 & 36 \\
\hline Tenenbaum Sz. & 1892 & 1940 & 41 & 236 & 85 & 46 \\
\hline
\end{tabular}

\section{CONCLUSIONS AND PROSPECTS}

The purpose of this article was to give a quantitative summary of the source material on one hand and to explore possible uses of spatial analysis applied to this type of data. Both approaches are supplementary and to some extent overlap, although the same data presented as a map are often much easier to analyze and therefore more in- 
formative. A part of the calculations could not be done quickly without using GIS techniques. However, data for such analyses have to be properly structured and cleaned, which is itself a time consuming process. In addition to this somehow trivial statement it is worth to add another one: the more the data, the more useful the effects of an analysis are.

Despite of the long tradition of entomological research in Poland and lots of specimens in numerous collections of many institutions, the modern type of faunistic analyses has not existed so far. The current article is probably the first case of this kind of integrated analysis. It was possible thanks to cooperation of the scientific institutions that initiated compiling data on Polish tenebrionids presented in the source article (IwAN et al. 2010), accompanied by recent achievements of the PolBIN and its integrative initiatives. The source data are planned to become a part of the database of Coleoptera Poloniae programme (coleoptera.ksib.pl), being realized by PolBIN members and aiming at creating an information system on Coleoptera of Poland. The more such datasets will be available, the more complete knowledge of species will be, making results of such analyses more representative and useful.

\section{REFERENCES}

Burakowski B., Mroczkowski M., Stefańska J. 1987. Chrząszcze Coleoptera. Cucujoidea. cz. 3. Katalog fauny Polski 23 (14): 1-309.

Burakowski B.. Mroczkowski M.. Stefańska J. 2000. Uzupelnienia tomów 2-21. Katalog fauny Polski 23 (22): 1-252.

Chapman A.D. 2005. Principles of data quality, version 1.0 Copenhagen: Global Biodiversity Information Facility.

Chapman A.D., Wieczorek J. (eds.) 2006. BioGeomancer Guide to Best Practices for Georeferencing. Copenhagen: Global Biodiversity Information Facility. 90 pp.

Iwan D.. Kubisz D.. Mazur M.A. 2010. The occurrence of Tenebrionidae (Coleoptera) in Poland based on the largest national museum collections. Fragmenta Faunistica 53(1): 1-95.

JoHnSON N.F. 2007. Biodiversity informatics. Annu. Rev. Entomol. 52:421-438.

Kozakiewicz M., Tykarski P. 2007. Różnorodność życia na Ziemi - wspólna troska. wspólne działanie, czyli o światowej sieci informacji o bioróżnorodności GBIF i jej polskiej części KSIB. Wszechświat 108(7-9):172-176.

Krishtalka L., Humphrey P. 2000. Can natural history museums capture the future? BioScience 50: 611-617.

Soberón J., A.T. Peterson. 2004. Biodiversity informatics: managing and applying primary biodiversity data. Philos. Trans. R. Soc. London B 359:689-698.

WHEELER Q.D. 2004. What is GBIF? Bioscience 54(8): 717. 


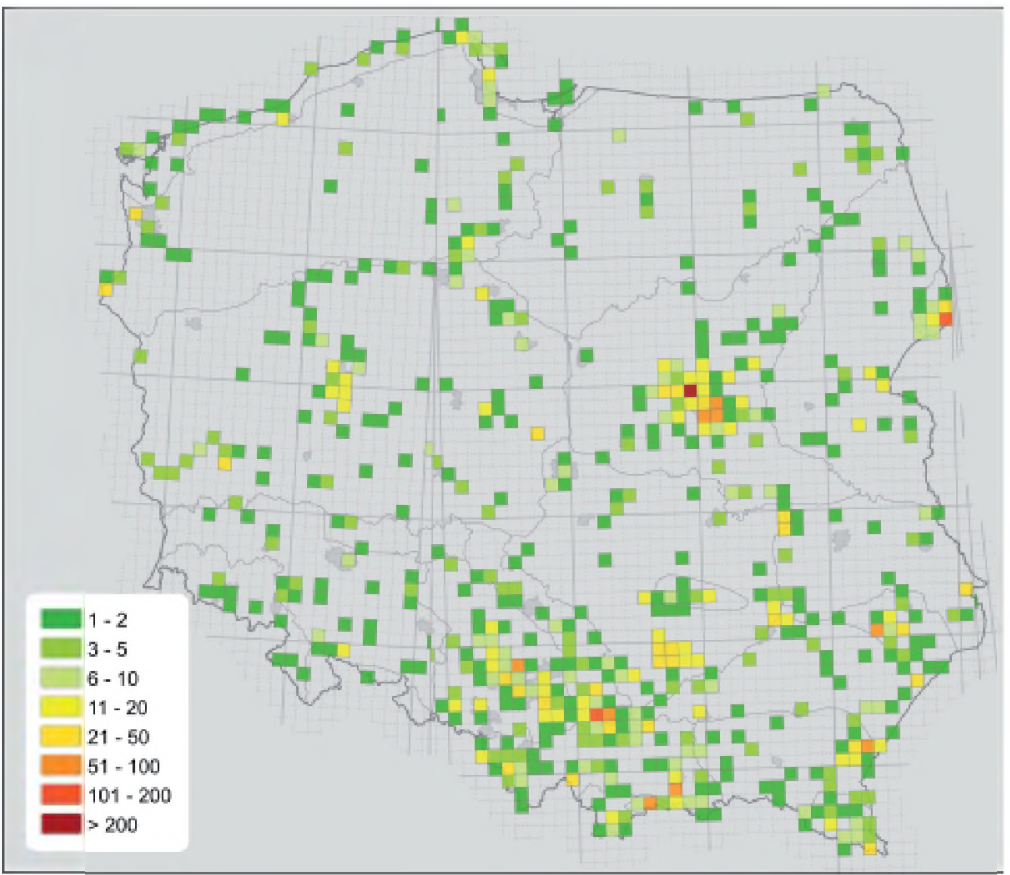

Fig. 3. Numbers of records from UTM squares, divided into classes coded with different colours.

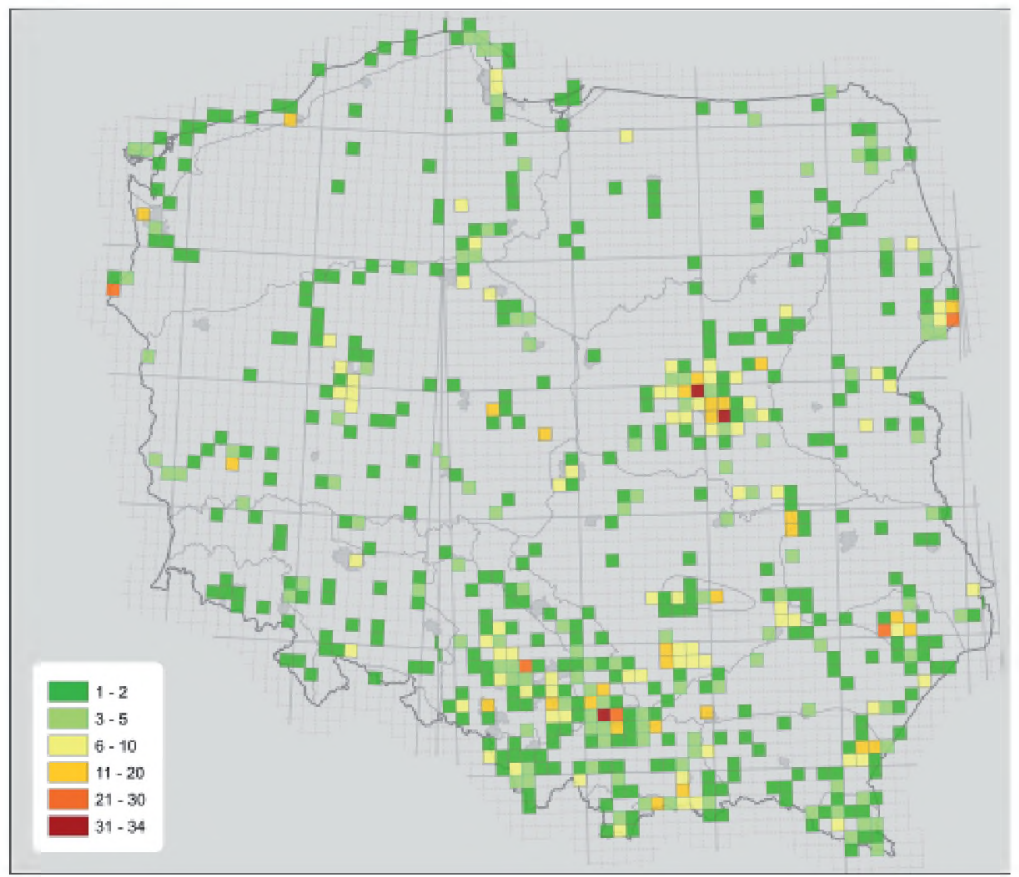

Fig. 4. Numbers of species recorded from UTM squares, divided into classes coded with different colours 


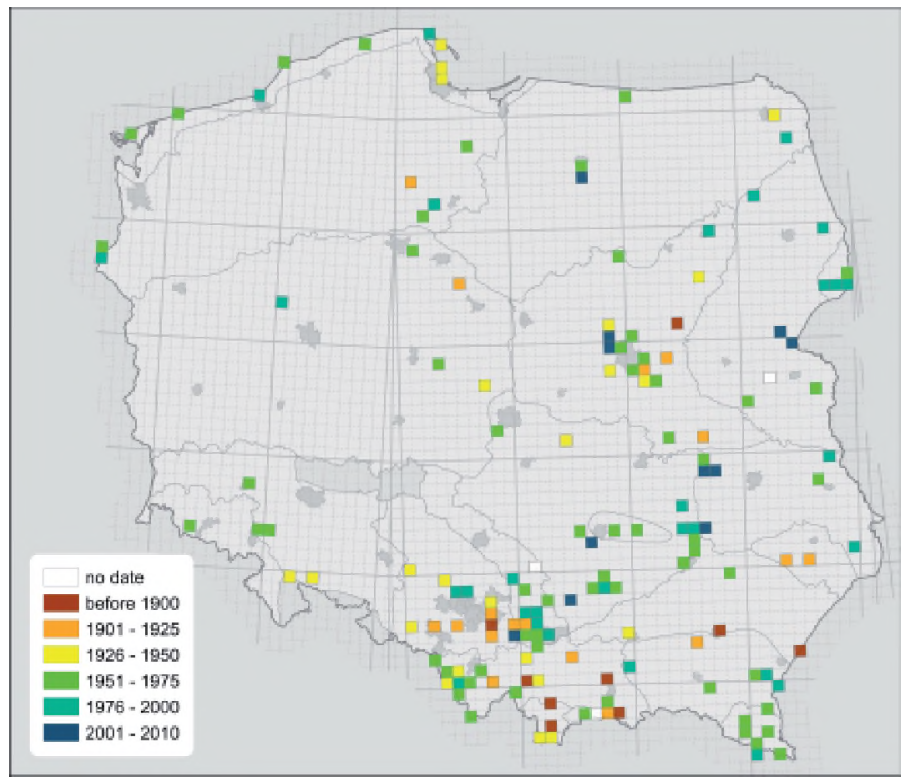

Fig. 5. Distribution of Lagria hirta - an example of a high similarity of general distribution information to the distribution data in KFP: the species was recorded in similar number of regions in the examined material and in the KFP. The colours code the year of the last record in a UTM square. Regions in light-grey were noted in KFP.

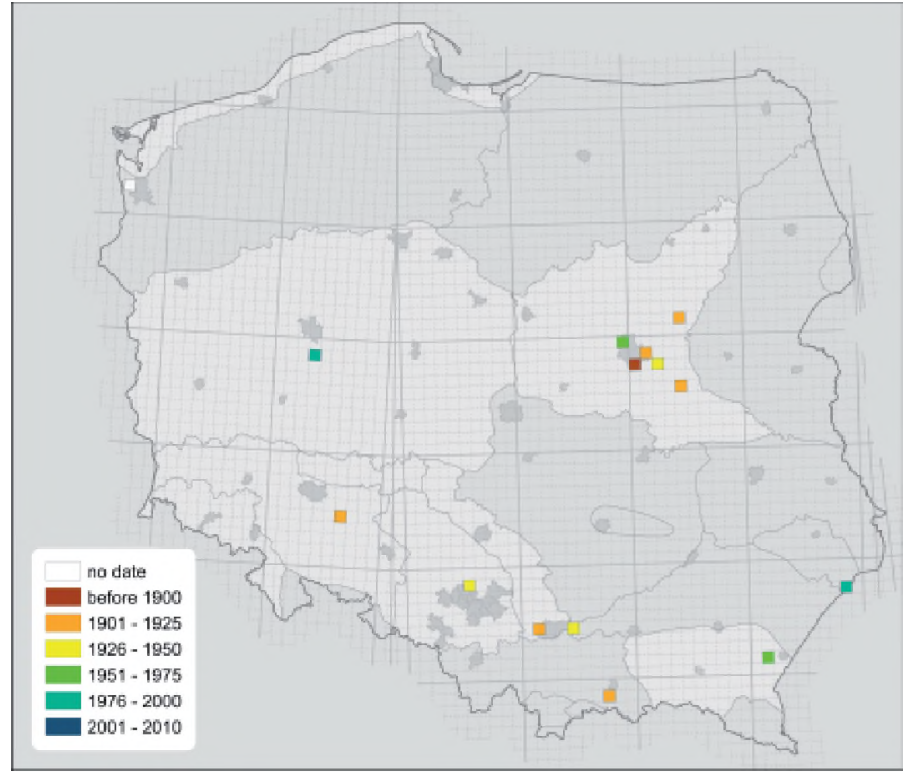

Fig. 6. Distribution of Corticeus fasciatus - an example of a low similarity of general distribution information to the distribution data in KFP: the species was recorded in different regions in the examined material and in the KFP. The colours code the year of the last record in a UTM square. Regions in light-grey were noted in KFP. 


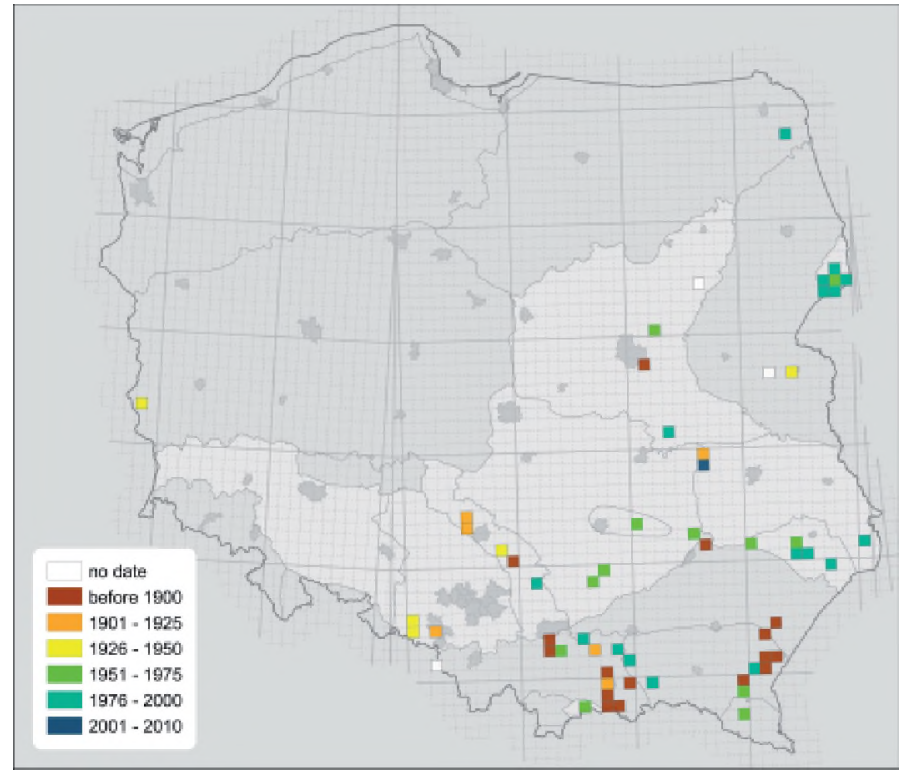

Fig. 7. Distribution of Stenomax aeneus - an example of a low similarity of a distribution in the analyzed material to the respective KFP data, with good coverage: the species was recorded in many regions that were not noted in KFP. The colours code the year of the last record in a UTM square. Regions in light-grey were noted in KFP.

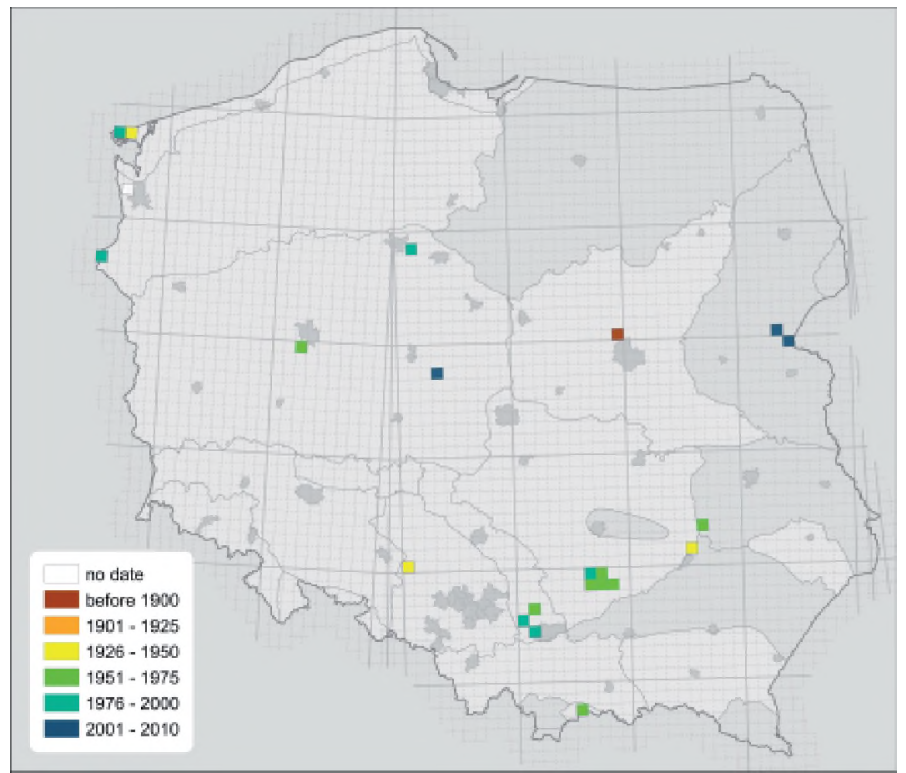

Fig. 8. Distribution of Hymenalia rufipes - an example of a low similarity of a distribution in the analyzed material to the respective KFP data, with low coverage: the species was recorded in many regions in KFP for which there are no data in the examined material. The colours code the year of the last record in a UTM square. Regions in light-grey were noted in KFP. 


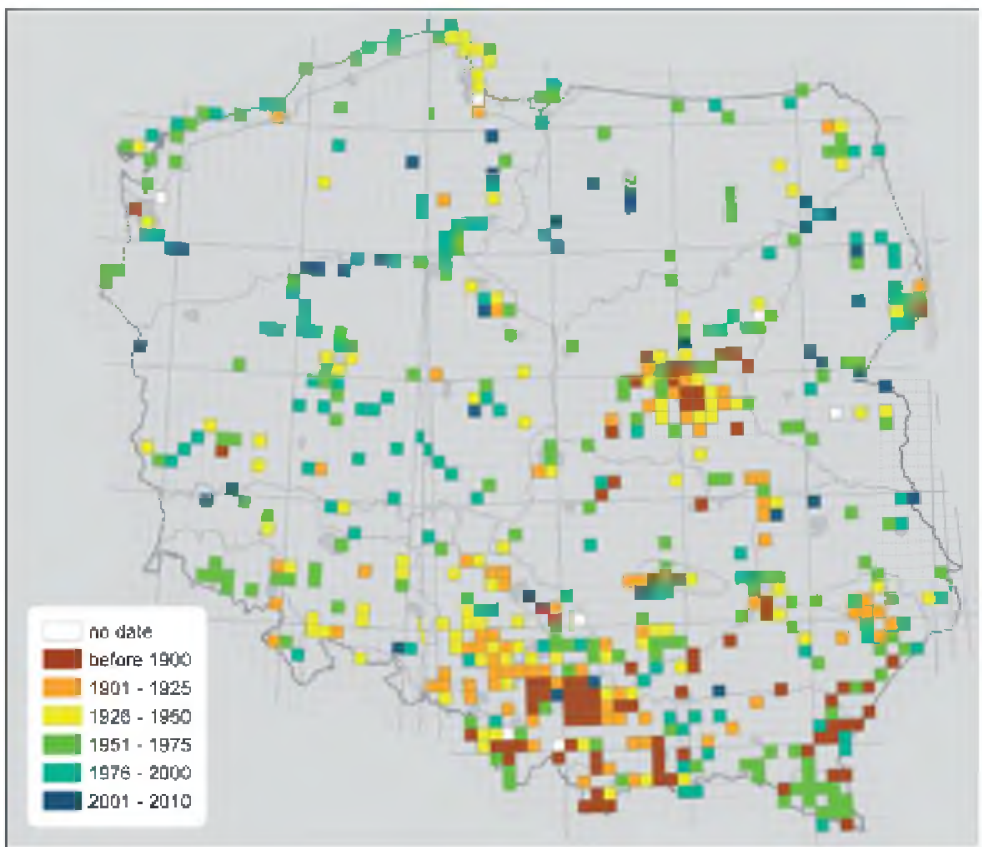

Fig. 9. Beginning of exploration at UTM squares of the source data. The colours code the year of the first record in a square.

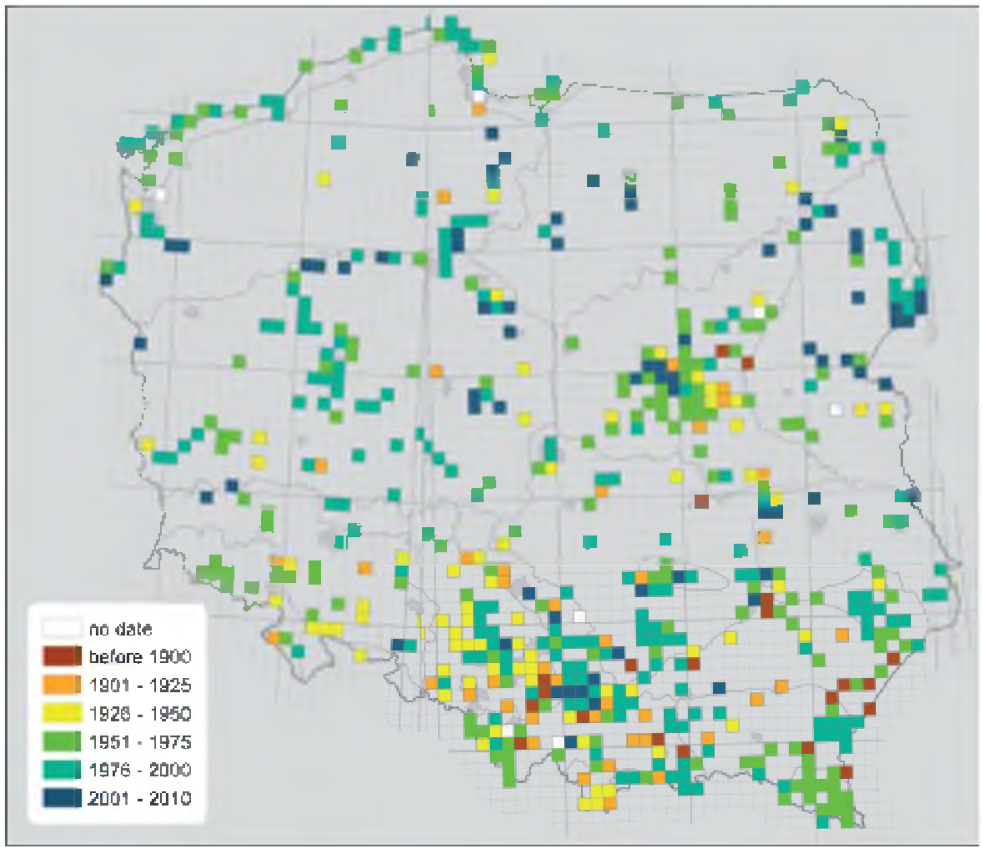

Fig. 10. Recent research at UTM squares of the source data. The colours code the year of the last record in a square. 


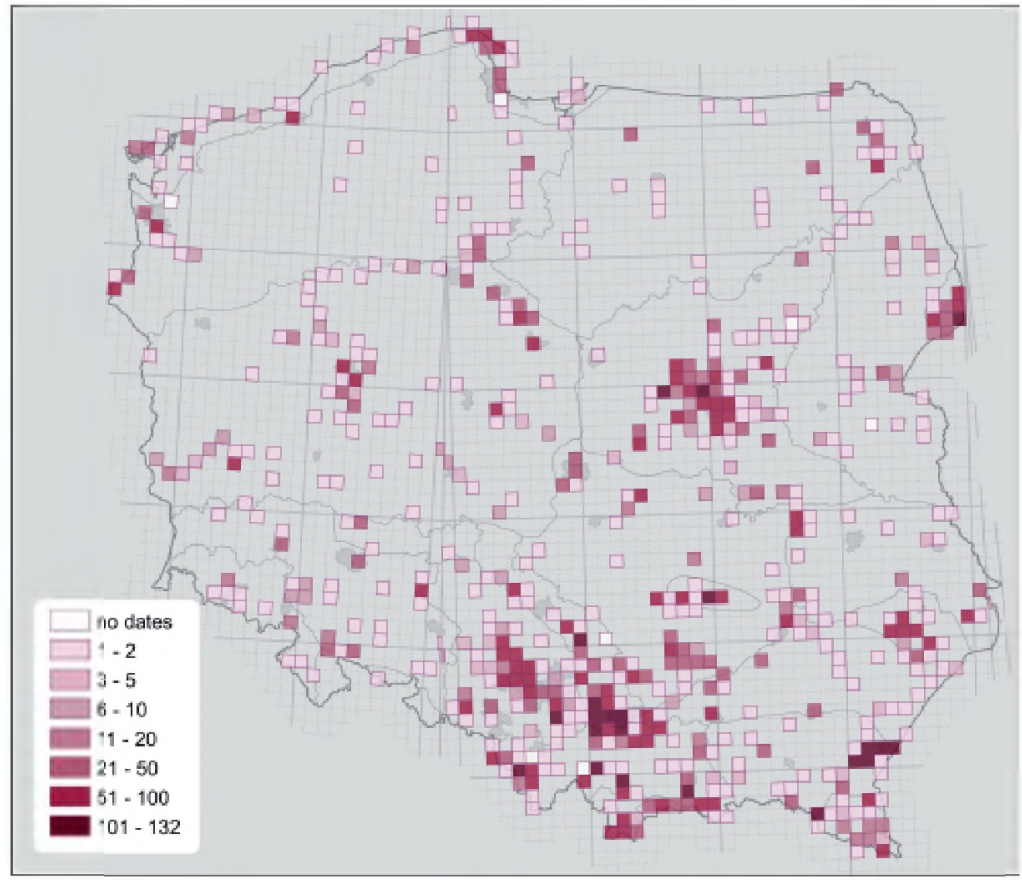

Fig. 11. Time range of research at UTM squares according to the source data - the period from a year of the first record to a year of the last record. The colours code classes of length of research.

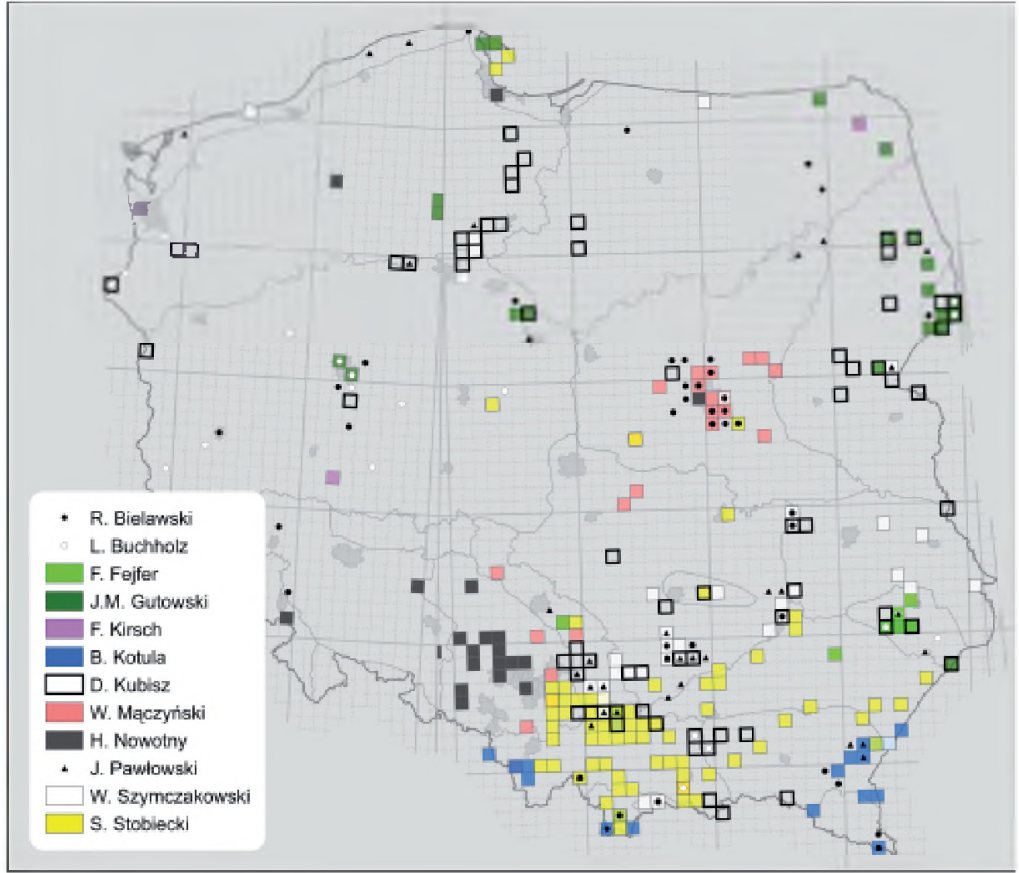

Fig. 12. Distribution of areas of activity of selected collectors - part 1. 


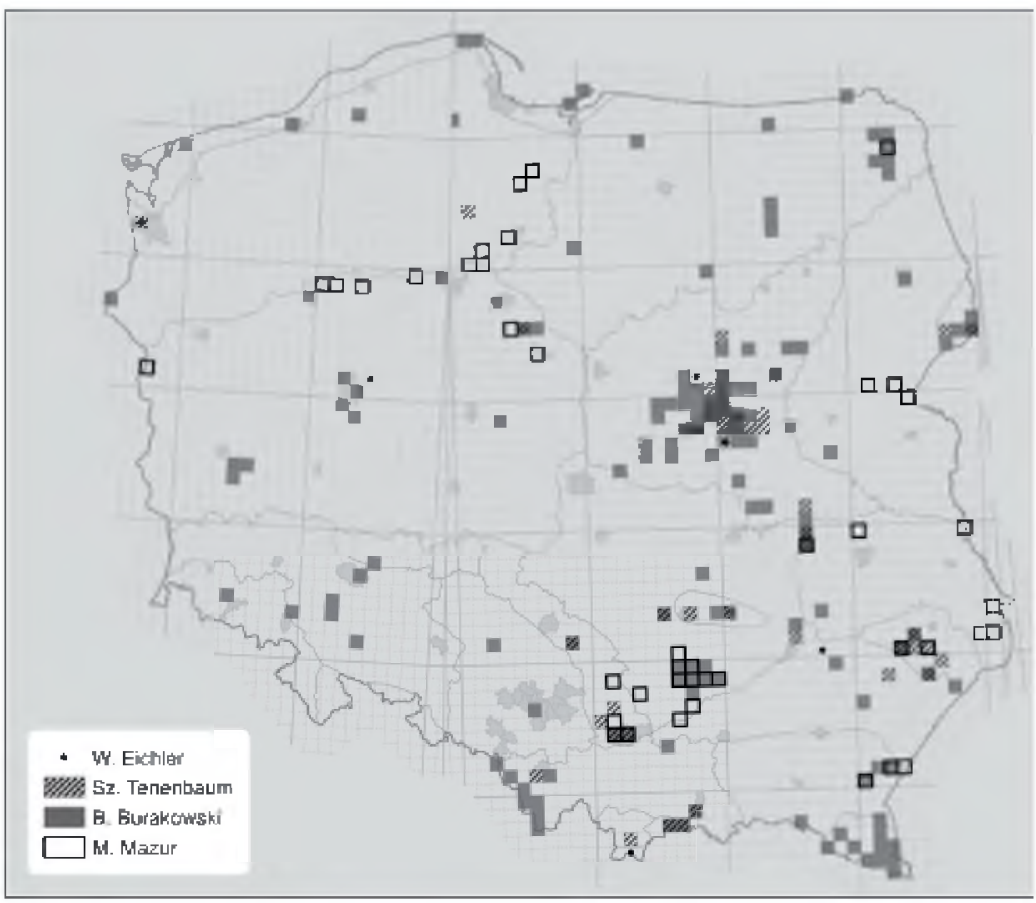

Fig. 13. Distribution of areas of activity of selected collectors - part 2.

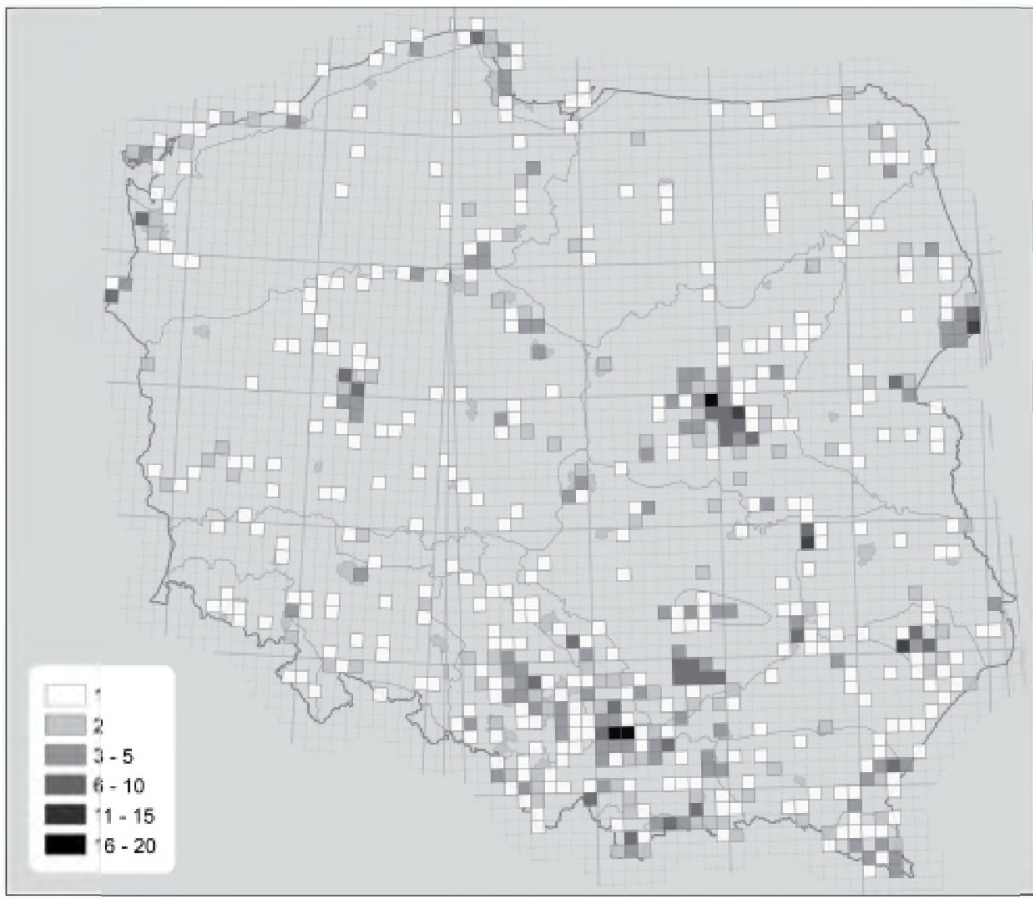

Fig. 14. Numbers of collectors active at UTM squares, divided into classes coded with different colours. 


\section{STRESZCZENIE}

\section{[Zakres i możliwości wykorzystania informacji zawartych w kolekcjach przyrodniczych - analiza na przykladzie największych polskich muzealnych kolekcji Tenebrionidae (Coleoptera)]}

Kolekcje okazów w muzeach przyrodniczych stanowią bogate źródło informacji i zawierają dane, które mogą znaleźć rozmaite zastosowania i być podstawą różnego typu analiz. Celem tego artykulu bylo zademonstrowanie możliwości wykorzystania potencjalu tkwiącego w tego typu zbiorach informacji poprzez analizę zawartości danych z trzech kolekcji czarnuchowatych (Coleoptera, Tenebrionidae), ze szczególnym uwzględnieniem korzyści zastosowania analiz przestrzennych. Analiza materiału źródlowego objęla podsumowania i zestawienia danych względem kolekcji (instytucji), gatunków i osób zbieraczy, dotyczace liczby rekordów, gatunków, lokalizacji, kwadratów UTM i dat pochodzenia okazów. Mapy ukazujace rozklad badanych wartości w różnych aspektach analizy okazaly się bardzo przydatne jako syntetyczny sposób prezentacji danych, często dużo wygodniejszy niż tradycyjna forma tabelarycznych zestawień. Ponadto bez wykorzystania technik GIS część obliczeń nie moglaby zostać wykonana, przynajmniej w sposób umożliwiający uzyskanie wyników w sensownym czasie.

Jest to najprawdopodobniej pierwsza w kraju tego typu analiza materialu faunistycznego, wykorzystujaca doświadczenia i metodologię wypracowaną w ostatnich latach w dziedzinie „biodiversity informatics”. Jest to obszar na styku nauk przyrodniczych i informatyki, w którym wykorzystuje się możliwości, jakie dają wspólczesne technologie informatyczne, do analiz danych przyrodniczych, między innymi tych uznawanych za tradycyjne i nienowoczesne. Techniki te staly się dostępne w Polsce m.in. poprzez rozwój międzynarodowej sieci GBIF i dzialania Krajowej Sieci Informacji o Bioróżnorodności. Niezależnie od aspektu technicznego tego typu analiz i związanych z tym wymagań co do jakości danych, podstawowym warunkiem zaistnienia samej możliwości ich przeprowadzenia jest zgromadzenie w jednym miejscu dużej ilości odpowiednich danych. Wymaga to efektywnej wspólpracy, zwykle na poziomie międzyinstytucjonalnym, takiej jaką zaprezentowali autorzy opracowania źródłowego dla niniejszego artykulu.

Dane z trzech omawianych kolekcji staną się elementem większego systemu informatycznego - bazy Coleoptera Poloniae - zaplanowanego na dhugie dzialanie programu KSIB, mającego za cel utworzenie pelnego źródla danych o krajowej faunie Coleoptera. Gdy dostępnych będzie więcej tego typu zbiorów danych, wyniki analiz rozmieszczenia gatunków będą bardziej reprezentatywne i znajdą szereg rzeczywistych zastosowań, niemożliwych do zrealizowania w tej chwili. 